\title{
The Ability of Avicennia marina to Uptake lons of Sodium and Chloride in Reed Bed System Reactor
}

\author{
Harmin Sulistiyaning Titah ${ }^{1 *}$, Ipung Fitri Purwanti ${ }^{1}$, Herman Pratikno ${ }^{2}$, Rachmi \\ Layina Chimayati', Handayanu ${ }^{2,}$ Siti Rozaimah Sheikh Abdullah', Nur 'Izzati \\ Ismail $^{3}$ \\ ${ }^{1}$ Department of Environmental Engineering, Faculty of Civil, Planning and Geo \\ Engineering, Sepuluh Nopember Institute of Technology, Keputih, Sukolilo, 60111 \\ Surabaya, Indonesia \\ ${ }^{2}$ Department of Ocean Engineering, Faculty of Marine Technology, Sepuluh Nopember \\ Institute of Technology, Keputih, Sukolilo, 60111 Surabaya, Indonesia \\ ${ }^{3}$ Department of Chemical and Process Engineering, Faculty of Engineering and Built \\ Environment, Kebangsaan Malaysia University, 43600, UKM Bangi, Selangor, Malaysia
}

\begin{abstract}
Many technologies can be used to solve the clean water crisis. One of the technologies is desalination, but this technology is expensive. So that, it is necessary to find cheaper desalination technology and easier to operate. Bio-desalination is a technology that utilizes bacteria to remove sodium and chloride ions in seawater. In this research, the application of the phytotechnology concept for bio-desalination reactors was carried out. Biodesalination technology used the uniqueness of mangrove plants (Avicennia marina) in a reed bed system reactor that adapted from a reed bed system commonly used in constructed wetlands (CWs). The aim of the research was to determine the uptake of sodium and chloride ions by Avicennia marina in a reed bed system biodesalination reactor. The namely of reactor were AM15\%, AM25\%, AMVA15\% and AMVA25\%. The VA code was shown that Vibrio alginolyticus addition in this reactor. The artificial saline water with initial salinity of $15 \%$ and $25 \%$ was chosen based on our previous study. Parameter of salinity was determined using salinometer. Concentration of sodium and chloride ions were analyses using ion chromatography. Based on the results, the concentration of sodium and chloride ions in Avicennia marina at AM15\%o were $843.18 \mathrm{mg} / \mathrm{kg}$ and $4959.96 \mathrm{mg} / \mathrm{kg}$, respectively. Meanwhile, those were $1410.01 \mathrm{mg} / \mathrm{kg}$ and $5292.64 \mathrm{mg} / \mathrm{kg}$ at AM25 \%o, respectively. The concentration of sodium and chloride ions in AMVA15\%o were $1003.39 \mathrm{mg} / \mathrm{kg}$ and $3186.96 \mathrm{mg} / \mathrm{kg}$, and it were $8036.43 \mathrm{mg} / \mathrm{kg}$ and $9783.91 \mathrm{mg} / \mathrm{kg}$ at AMVA25\%. The
\end{abstract}

\footnotetext{
* Corresponding author: harminsulis@gmail.com, harmin st@its.ac.id
} 
value of Bio-concentration Factor (BCF) and Translocation Factor (TF) were greater than 1 , it indicated that Avicennia marina was as an hyperaccumulator plant for sodium and chloride ions. In conclusion, the Avicennia marina can be used in reed bed system bio-desalination reactor to reduce salinity.

Keywords. Bio-desalination, hyperaccumulator, mangrove, reed bed system, salinity

\section{Introduction}

Mangroves are perennial woody plants grown in tropical and sub-tropical inter-tidal zones [1]. Many species of mangrove plants can grow in high range of salinity. Based on our previous study [2,3], Avicennia marina and Rhizophora mucronata can survive until salinity of $30 \%$. The tolerance of mangrove species to salinity followed the sequence of Avicennia alba, Avicennia marina, Rhizophora apiculate, Rhizophora stylosa, Ceriops tagal, Achantus ilicifolius, this condition was supported their natural species distribution and habitat zones [4]. According to Saeni and Tanasale (1999] [5], mangrove can be used to reduse salinity. Based on our earlier study, the reduction of salinity reached up to $92 \%$ at a treatment using Avicennia marina in a batch reed bed reactor after 2 to 4 days of operation [6]. The other previous study reported the best percentage decline of salinity reached $90 \%$ at a treatment using Avicennia marina and Rhizophora mucronata with addition of Vibrio alginolyticus in a continues reed bed reactor after 6 day of running. The salinity reduction was $25 \%$ to $1.99 \%$ [7].

According to Scholander et al., (1962) [8], mangrove plants were divided into two groups, namely secretor and non secretor. Genus of Aegialitas, Aegiaceras and included in secretor plant. The concentration of sodium chloride in xylem was relatively high, and the ratio was 11:10 part of the concentration of seawater. The salinity absorption occurred through the salt gland metabolism. The released salinity can be crystallized through evaporation processes. The second group were Bruguiera, Lumnitzera, Rhizophora, and Sonnerata. The ration of sodium chloride and seawater was 11: 100 in xylem. However, it was 10 fold higher than non-mangrove plants. Although the non-secretor plants have a no special mechanism to actively extract salt, this plant released salt through the leaf surface (possibly via cuticular transpiration).

The aim of this research was to determine the uptake of sodium and chloride ions by Avicennia marina in a batch reed bed system bio-desalination reactor.

\section{Materials and Methods}

\subsection{Mangrove Preparation}

Plants of Avicennia marina were collected from nursery of mangrove at Mangrove Forest, Wonorejo, Surabaya. The age of Avicennia marina was around 3 months. Fig. 1 described the Avicennia marina acclimatization at greenhouse at Remediation Laboratory, Department of Environmental Engineering, ITS before those plants were applied in research. 


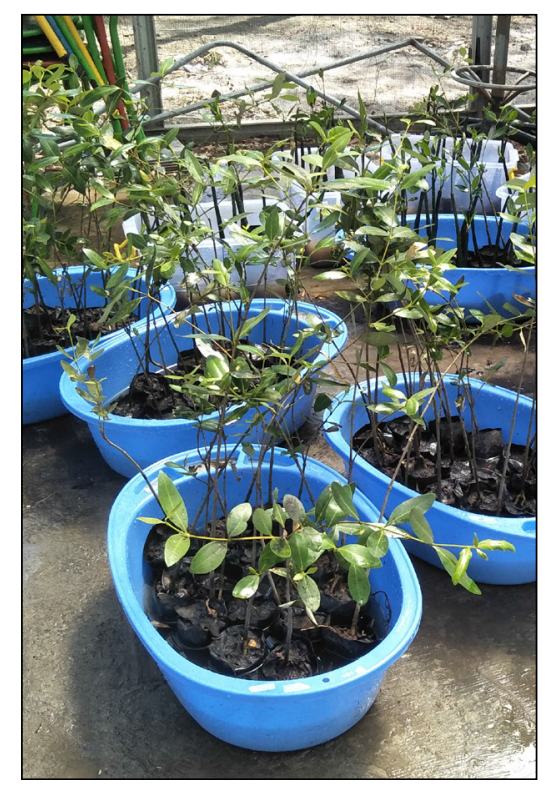

Fig. 1. Avicennia marina acclimatization.

\subsection{Reactor Preparation}

The description of the reed bed system reactor was showed at Fig.2. Based on the figure, the dimensions of the reactors were $31.5 \times 31.5 \times 65.5 \mathrm{~cm}$. The bottom layer was a double layer of gravel with $2 \mathrm{~cm}$ and $1 \mathrm{~cm}$ of diameter. The height of gravel layer was $5 \mathrm{~cm}$. After then, the layer filled with $2 \mathrm{~L}$ of water After that, a sand layer was put with $10 \mathrm{~cm}$ of high. The saturated water in second layer was $1.8 \mathrm{~L}$. And the top layer was artificial saline water with sinitial salinity of $15 \%$ and $25 \%$. Fig. 2 described the reed bed system reactor. Fig. 2 (a) showed the treatment without bacteria addition, meanwhile Fig. 2 (b) showed bacteria of Vibrio alginolyticus addition for treatment. There were 8 reactors, with duplo replicates, namely were AM15\%o, AM25\%, AMVA15\%o and AMVA25\%. Fig. 3 depicted the photograph during treatment running. 


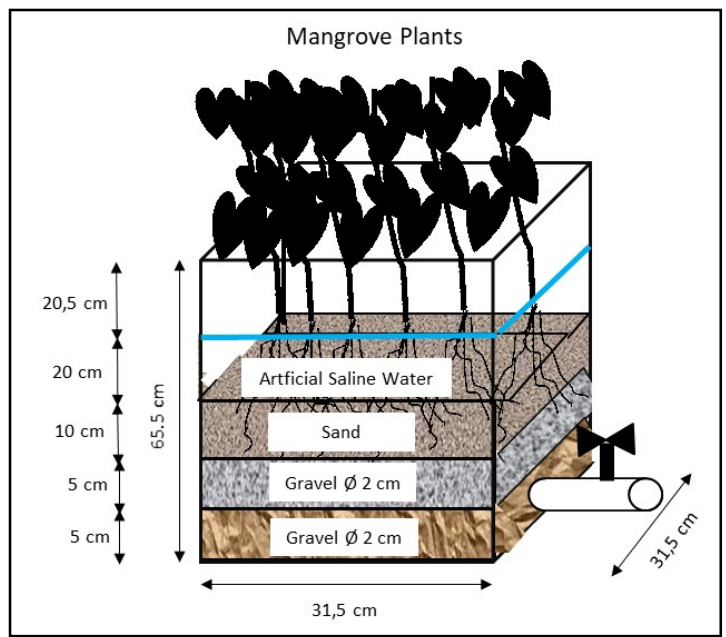

(a)

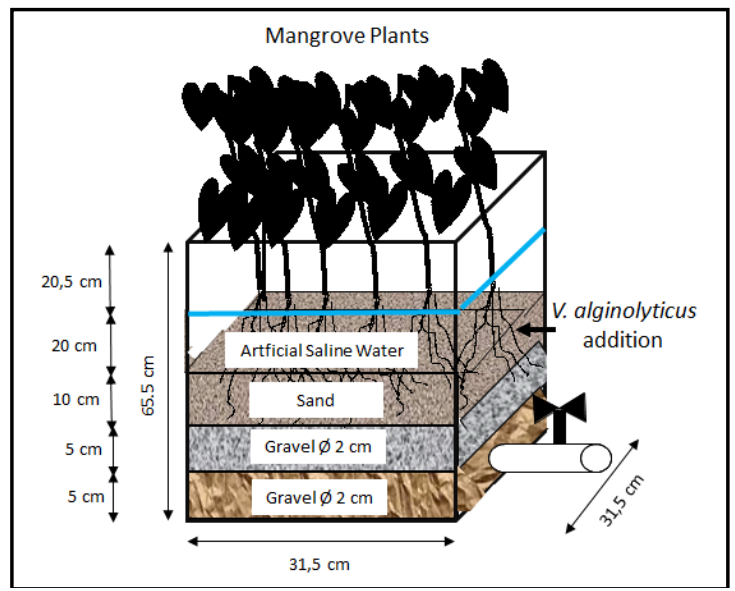

(b)

Fig. 2. A reed bed system bio-desalination reactor

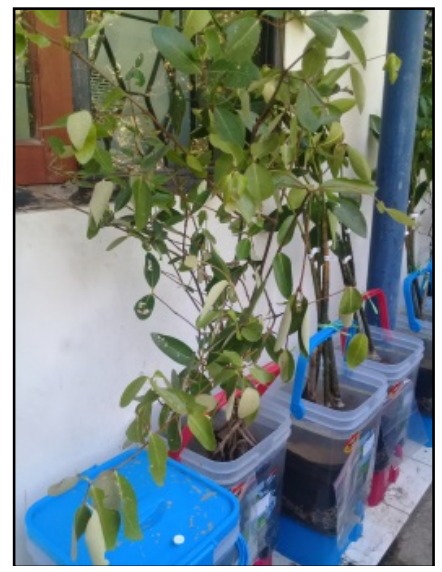

Fig. 3. Avicennia marina was planted in a reed bed system bio-desalination reactor 


\subsection{Artificial Salinity Preparation}

The artificial saline water with initial salinity of $15 \%$ and $25 \%$ was chosen based on our previous study [2,3]. The preparation of artificial salinity was conducted based on our previous study [2].

\subsection{Preparation of Bacteria}

This research was carried out using species bacteria of Vibrio alginolyticus. The pure culture of bacteria was be inoculated onto nutrient agar (NA) media using streak plate technique [9]. The age of bacteria that was ready to be used was $24 \mathrm{~h}$. After that, one colony of bacteria was tranferred to nurient borth (NB), and kept in shaker of Innova 2000 (New Brunswick-Eppendorf, Jerman) at $150 \mathrm{rpm}$ and room temperature, $33{ }^{\circ} \mathrm{C}$ for $24 \mathrm{~h}$ [10]. After that, the value of Optical Density (OD) of bacterial suspension was measured using spectrophotometer model Genesys 20 (Thermo, USA). If the value OD was 1, it was ready to be used in bio-desalination red bed system reactor.

\subsection{Parameter Analysis}

Parameter of salinity was determined using salinometer. All samples of root, stem and leave were dried at $105^{\circ} \mathrm{C}$ for $24 \mathrm{~h}$. After that, each sample was extracted using extraction process for anions based on Stanisic et al. 2011a [11] and it used method based on Stanisic et al. $2011 \mathrm{~b}$ [12] for cations. All extraction used de-ionized water. A total of $5 \mathrm{~g}$ of dried samples was added to $10 \mathrm{~mL}$ of de-ionized water $(1: 10)$ and extracted using a rotary agitator at 60 rpm for 1 hour at room temperature. The samples were centrifuged using a centrifuge model Jouan E82 (Thermo, USA) at $3000 \mathrm{rpm}$ for 10 minutes and then filtered using a filter paper (Whatman, Germany). After that, samples were placed in bottle sample and it were kept in a refrigerator $\left(-4^{\circ} \mathrm{C}\right)$. The analysis of sodium and chloride concentration in part of Avicennia marina were conducted using ion chromatography (IC), Metrohm, type of 882 Compact plus (Switzerland).

\section{Results and Discussions}

Fig. 4 showed the concentration of sodium and chloride in part of Avicennia marina i.e roots, stems, and leaves after two weeks exposure with sinitial alinity of $15 \%$ and $25 \%$. This indicated that Avicennia marina can uptake the sodium due to this plant included as a secretor group of mangrove [8]. Generally, the concentrations of sodium ion and chloride ion at all treatments were high in stems, except at code treatment of AMVA25\%. However, the sodium concentration in roots, stems and leaves at code treatment of AMVA25\%o showed the highest value among the others treatments. Those value were $1413.24 \mathrm{mg} / \mathrm{kg}$. $1242.45 \mathrm{mg} / \mathrm{kg}$ and $531.27 \mathrm{mg} / \mathrm{kg}$, respectively at roots, stems, and leaves. 


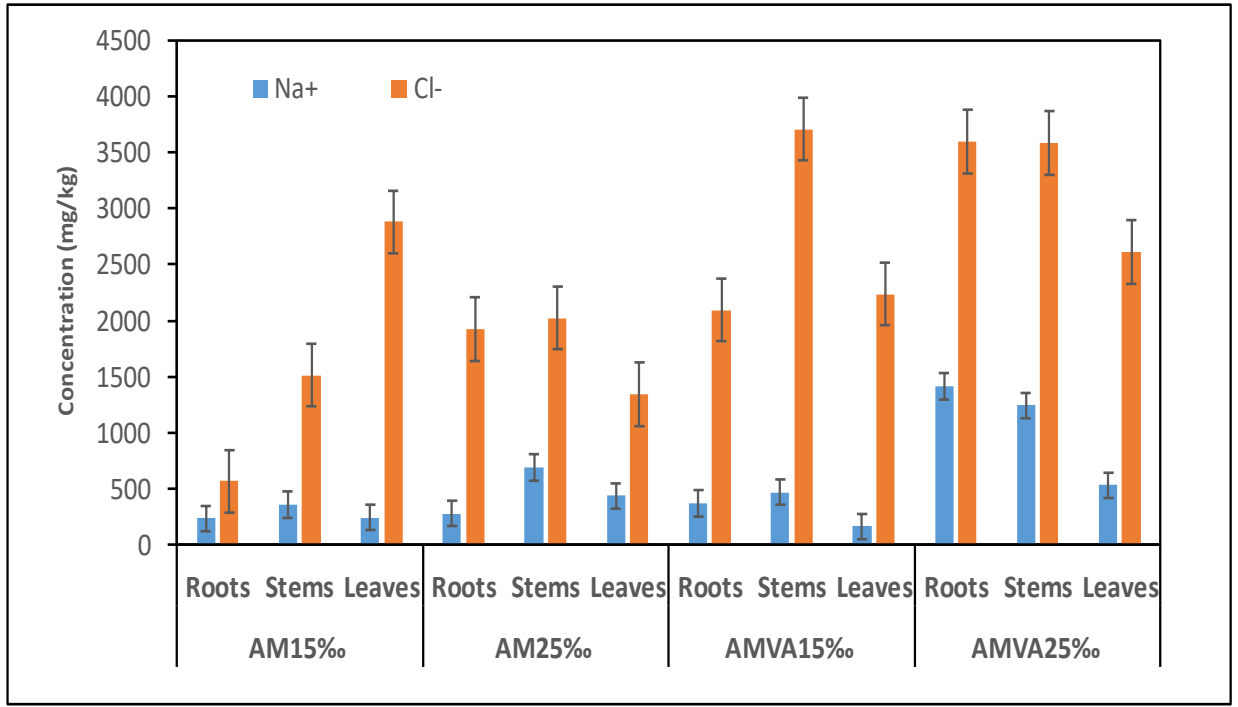

Fig. 4. Ions concentration of sodium and chloride in part of Avicennia marina

Explanation, AM15\% = treatment with Avicennia marina at $15 \%$, AM25\% = treatment with Avicennia marina at $25 \%$, AMVA15\% = treatment with Avicennia marina and addition of Vibrio alginolyticus bacteria at $15 \%$, and AMVA25\% = treatment with Avicennia marina and addition of Vibrio alginolyticus bacteria at $25 \%$.

Fig. 5 showed the sodium and chloride concentration in a whole plant of Avicennia marina. The highest of sodium and chloride concentration occurred at treatment of AMVA25\%. Based on our previous study, Titah et al. (2019a) and Titah et al. (2019b) [2,3], Avicennia marina and Rhizophora mucronata can take up sodium and chloride, and then, sodium and chloride are translocated to aerial part, stems and leaves. Based on scanning electron microscopy-energy dispersive X-ray (SEM-EDX) results in our previous study about phytotoxicity of salinity on Avicennia marina, the sodium and chloride weight concentration were founded in root, shoot and leaves, respectively [2]. Mangroves accumulate high concentrations of inorganic ions like most other salt-tolerant plants that function in the osmoregulation of leaves and other tissues [13]. Avicennia marina has the ability to regulate salt content by secreting it through the glands [14] due to Avicennia marina included in as a secretor group of mangrove. The mangrove can decrease salinity, chiorinity, and conductivity of water, except for water which did not contain sea water. The increasing of chloride ion in the tissues was influenced by the increase of chloride ion in root tissues [5]. 


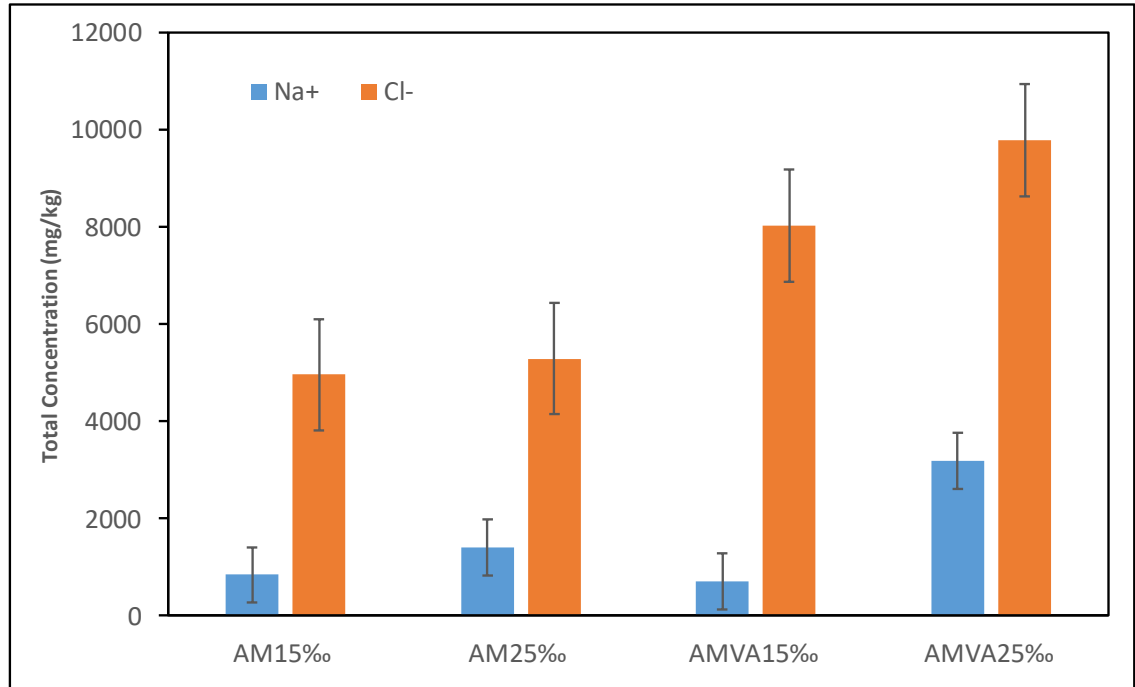

Fig. 5. Ions concentration of sodium and chloride in whole plants of Avicennia marina Explanation, AM15\% = treatment with Avicennia marina at $15 \%$, AM25\% $=$ treatment with Avicennia marina at $25 \%$, AMVA15\% = treatment with Avicennia marina and addition of Vibrio alginolyticus bacteria at $15 \%$, and AMVA25\% = treatment with Avicennia marina and addition of Vibrio alginolyticus bacteria at $25 \%$.

Fig. 6 depicted the value of Bioconcentration Factor (BCF) and Translocation Factor (TF) for ion of sodium and chloride. BCF was the concentration of test substance in organisms or tissues $(\mathrm{mg} / \mathrm{kg}) /$ concentration of the substance in media $(\mathrm{mg} / \mathrm{L})$, meanwhile the TF was the concentration of test substance in stem $(\mathrm{mg} / \mathrm{kg}) /$ concentration of the substance in root $(\mathrm{mg} / \mathrm{kg})$.

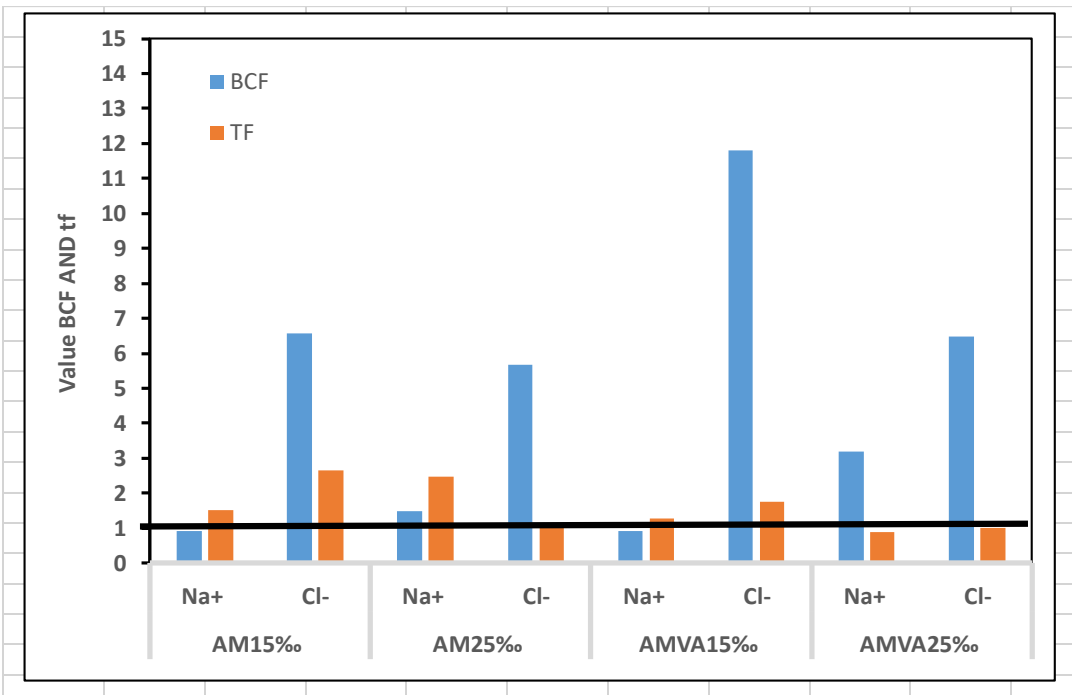

Fig. 6. Value of $\mathrm{BCF}$ and $\mathrm{TF}$ for ion of sodium and chloride

Explanation, AM15\% = treatment with Avicennia marina at $15 \%$, AM25\% $=$ treatment with Avicennia marina at $25 \%$, AMVA15\% = treatment with Avicennia marina and addition of Vibrio alginolyticus bacteria at $15 \%$, and AMVA25\% = treatment with Avicennia marina and addition of Vibrio alginolyticus bacteria at $25 \%$. 
Based on the Fig. 6, the value of BCF were upper than 1 for sodium and chloride ions. Similar condition, the value of TF was upper than 1 for sodium and chloride ions. It indicated the Avicennia marina was a hyperaccumulator plant for sodium and chloride ions.

\section{Conclusions}

The concentration of sodium and chloride ions in Avicennia marina at AM15\%o were $843.18 \mathrm{mg} / \mathrm{kg}$ and $4959.96 \mathrm{mg} / \mathrm{kg}$, respectively. Meanwhile, those were $1410.01 \mathrm{mg} / \mathrm{kg}$ and $5292.64 \mathrm{mg} / \mathrm{kg}$ at AM25\%, respectively. The concentration of sodium and chloride ions in AMVA15\%o were $1003.39 \mathrm{mg} / \mathrm{kg}$ and $3186.96 \mathrm{mg} / \mathrm{kg}$, and it were $8036.43 \mathrm{mg} / \mathrm{kg}$ and $9783.91 \mathrm{mg} / \mathrm{kg}$ at AMVA25\%. The value of BCF and TF were greater than 1, it indicated that Avicennia marina was as an hyperaccumulator plant for sodium and chloride ions. In conclusion, the Avicennia marina can be used in reed bed system bio-desalination reactor to reduce salinity.

\section{Acknowledgement}

The author would like to thank Kementerian Riset dan Teknologi/ Badan Riset dan Inovasi Nasional, Indonesia through scheme of Penelitian Dasar Unggulan Perguruan Tinggi - third year research, PDUPT 2020 for funding this research with No of contract, 3/E1/KP.PTNBH/2020, and No of amendment contract, 3/AMD/E1/KP.PTNBH/2020, and No. 1171/PKS/ITS/2020.

\section{References}

1. N.F Tam, Y. Wong. 2014 4th International Conference on Future Environment and Energy IPCBEE vol.61 (2014)

2. H.S. Titah, I.F. Purwanti, H. Pratikno, R.L. Chimayati, Handayanu. Journal of Ecological Engineering. 20(3), 126-134 (2019a)

3. H.S. Titah, I.F. Purwanti, H. Pratikno, R.L. Chimayati. Ecology, Environment and Conservation. 25, 32-39 (2019b)

4. M. Basyuni, Ramayani, A. Hayullah, Prayunita, M. Hamka, L.A. Putri and S. Baba. IOP Conf. Ser. Earth Environ. Sci. 236 012050. (2019)

5. M.S. Saeni and F.J.D.P Tanasale. Project Mangrove. (1999)

6. R.L. Chimayati and H.S Titah. Journal of Ecological Engineering. 20(4): 84-93. (2019)

7. T.C. Puspaningrum and H.S Titah. Journal of Ecological Engineering. Accepted Paper. (2020)

8. P.F. Scholander, H.T. Hammel, E. Hemmingsen, and Carey. Plant Physiol., 37, 722729. (1962)

9. H.P. Harley, L.M. Prescott LM. Laboratory exercises in microbiology. fifth Edition. MGraw-Hill Companies, Texas, (2002)

10. H. Pratikno, and H.S. Titah. Asian J Appl Sci., 9, 120-125. (2016)

11. M.S. Stanišić, M.I. Ljubiša, C.S. Milica, and C.S. R.D. Aleksandar. Journal the Serbian. Chemical. Society 76(5): 769-780. (2011a)

12. M.S. Stanišić, M.I. Ljubiša, D.D. Manojlovic, and B.P. Dojcinovic. Central European Journal of Chemistry 9(3): 481-491. (2011b)

13. J. Hegemeyer. In: Prasad, M.N.V. (ed.), pp. 173-206. John Wiley \& Sons, Inc. New York. (1997) 
14. M. Popp, In: Dietmar, H., Luttge, U., Esser, K., Kaderelt, J.W. and Runge, M. (eds.), pp. 416-429. Springer Verlag, Berlin. (1994) 